\title{
TRAUMATIC SPINAL PARALYSIS IN CHILDREN
}

\author{
By Dr. David C. Burke, M.B., B.S.(Melb.), D.P.R.M. \\ Spinal Injuries Centre for Victoria Austin Hospital, Heidelberg, and \\ Spinal Cord Injury Service, Rancho Los Amigos, Downey Hospital, California (U.S.A.)
}

IN a previous paper (Burke, I97I) the author drew attention to some of the unusual presenting features in children under 13 years of age who sustained traumatic paraplegia. Seven children were described in some detail, all of whom had complete spinal cord lesions with absent or minimal radiological evidence of vertebral injury. The similarity of this syndrome with spinal cord injury sustained as a birth injury was noted. In the absence of any information on the skeletal and neural pathology in the literature from autopsy material, or from the author's reported cases (all of whom survived and none of whom were explored surgically), a hypothetical explanation of the mechanism and pathology of these injuries was advanced.

Whilst working on the Spinal Cord Injury Service at Rancho Los Amigos Hospital in Downey, California, the author reviewed the hospital's medical records. The case notes and X-rays of all children who sustained spinal cord injuries under the age of 13 years were studied. It was felt that some useful information on the pathology of these lesions might be found from autopsies and from the observations of surgeons at laminectomy as it was known that operation is very frequently performed in the United States. It was also hoped that some information on survival might be obtained as this is another subject which is barely mentioned in the literature. It should be noted that the conclusions reached and opinions expressed in this paper are those of the author and not necessarily those of the Staff of Rancho Los Amigos Hospital.

\section{MATERIAL}

The case notes and X-rays were studied of every child who had been treated at Rancho Los Amigos Hospital, and who had sustained a spinal cord injury under the age of 13 years. There were 29 patients, the injuries having occurred up to I8 years previously. Five children with spinal paralysis from birth injuries were included in the study as it is probable that the pathology of these injuries is similar to those occurring after birth. Penetrating injuries, such as those due to gunshot wounds were excluded. None of the children were admitted directly to Rancho Los Amigos Hospital, initial treatment having been carried out at a variety 
of other hospitals. Transfer to Rancho varied between I week and 3 years after injury.

\section{RESULTS}

Birth Injuries. There were five patients, two males and three females. Four were delivered by the breech, and one by the vertex (vaginal delivery during Caesarian section for difficult labour). Neurological lesions were as shown in Table I. Four of the five patients had no evidence of bony injury on X-ray. The patient with an incomplete lesion below the fourth cervical level had a gross extension injury of the fourth cervical vertebra on the fifth cervical vertebra after a breech delivery. A myelogram was only performed on one patient, one with no bony injury. This was normal.

Laminectomy was done on one patient, the child with the gross extension injury. Contusion and marked swelling of the spinal cord was noted. One of the patients who had no bony injury died after seven years, but as an autopsy was not performed no information is available about the pathology of the spinal cord injury.

\section{TABLE I}

Levels of neurological lesions

Birth Injuries

$\begin{array}{llll}\text { Incomplete below } \mathrm{C}_{4} & \text { I } & & \\ \text { Complete below } \mathrm{C}_{7} & 2 & \text { Complete lesions } & 3 \\ \text { Incomplete below C8 } & \text { I } & \text { Incomplete lesions } & 2 \\ \text { Complete below } \mathrm{T}_{3} & \text { I } & & \end{array}$

\begin{tabular}{|c|c|c|}
\hline \multicolumn{3}{|c|}{ Post-Birth Injuries } \\
\hline $\mathrm{CI}_{\mathrm{I}}-\mathrm{C}_{4}$ & 2 & \\
\hline $\mathrm{C}_{5}-\mathrm{C} 8$ & 7 & \\
\hline $\mathrm{T}_{\mathrm{I}}-\mathrm{T}_{4}$ & $6)$ & Complete lesions 22 \\
\hline $\mathrm{T}_{5}-\mathrm{T}_{9}$ & $5\}^{11}$ & Incomplete lesions 2 \\
\hline T9-TI2 & 3 & \\
\hline Below Ti2 & $\mathbf{I}$ & \\
\hline
\end{tabular}

Other Injuries. There were I I males and I 3 females in the series. Age at injury was fairly wide spread, ranging from 9 weeks to 12 years. It was found that ro of the 24 were aged less than 2 years, showing a higher incidence in the very young. The commonest cause by far was motor vehicular accidents. These either as passengers in cars or other vehicles, or as pedestrians (Table II). Some of the 'pedestrians', as in the Melbourne series, were crawlers run over by a motor 
vehicle at home. The neurological lesions were predominantly lower cervical and upper to mid thoracic, as with the birth injuries (Table I). Only two of the 24 patients had incomplete lesions; one of the complete lesions was in fact incomplete before laminectomy was performed. A similar high proportion of complete lesions was noted with the birth injuries.

\section{TABLE II}

Causes of injury

$\begin{array}{lr}\left.\begin{array}{lr}\text { Passenger in motor vehicle } & \text { I0 } \\ \text { Pedestrian, knocked over by car } & 6\end{array}\right\} \text { I6 } \\ \text { Fall from height } & 7 \\ \text { Struck by falling steel bar } & \text { I }\end{array}$

Twelve patients (50 per cent.) had no evidence of bony injury on X-ray. Another seven patients had minimal bony injuries, consisting of minor compression fractures or vertebral bodies or slight forward subluxations. Only five had major fracture dislocations, four of the flexion rotation type, and one extension disruption. Myelography was performed on nine patients, including eight of those with no bony injury. Myelography was normal in five of the eight, showed a partial block on one, a complete block six segments below the neurological lesion on one, and a partial 'extradural' block was reported in the other. One myelogram was performed on a patient with a minimal compression fracture of the third thoracic vertebra-this was normal. The results of lumbar puncture were recorded for three patients only; in two the cerebrospinal fluid was said to be blood stained, but there was no block, in the third there was said to be 'partial block', but no myelogram was performed.

Operative Findings. Primary treatment of the spine of the 29 patients consisted of laminectomy in I3, but laminectomy was only performed on three of the I6 patients who had no bony injury on X-ray. As the operations were all performed at other hospitals prior to transfer to Rancho Los Amigos Hospital the reports of findings in the referring letter were often brief. Operative findings were reported as a normal-looking spinal cord in four, swelling and contusion of the spinal cord in three, and laceration and 'maceration' of the spinal cord in three. In one patient, who had a paraplegia, an extradural haemorrhage was found compressing a contused spinal cord at the tenth thoracic level with a lesion complete below the fourth thoracic segment. This patient leads to most interesting conjecture concerning the pre-operative assessment of the patient, and the surgeon's intention. It also leads to mechanical and pathological speculations which will be developed later. No information was available of the findings at laminectomy on two patients. The findings in the three patients who had no bony injury consisted of 'contusion of the right side of the spinal cord at the tenth/eleventh thoracic level', 'pulped cord and torn disc at the second/third thoracic level with extradural haemorrhage' and 'cord contused and compressed by extradural haemorrhage between the tenth thoracic and second lumbar vertebra', the latter in the patient with the complete lesion below the fourth thoracic segment. The patient with the 'pulped cord' in the upper thoracic region had a partial block on myelography, as did the patient with a right-sided contusion of the spinal cord at the tenth thoracic level. 
The latter, who was incomplete pre-operatively, has remained complete since laminectomy.

Mortality. Two of the 29 patients died, including one birth injury. Post mortem was only performed on one. An I I-month-old child with complete tetraplegia below the fifth cervical segment died $3 \frac{1}{2}$ months after injury, of bronchopneumonia (autopsy finding). Another tetraplegic, from a birth injury, was complete below the seventh cervical segment and died after 7 years probably also of respiratory causes as she had a permanent tracheostomy and required intermittent positive pressure respiration (no autopsy).

Autopsy Findings. It was noted at post mortem that the cervical spinal cord had 'a constricted area (compressed) for four centimetres above the cervical enlargement' in the II-month-old child with complete tetraplegia below the fifth cervical segment. An autopsy was not performed on the other patient who died.

Survival. Apart from the two deaths after $3^{\frac{1}{2}}$ months and 7 years, respectively, the remainder of the children have survived between 3 months and I 8 years. Three are alive more than 15 years after injury, three between 10 and I 5 years, six between 5 and Io years, I I between I and 5 years, and six were in their first year after injury.

In any consideration of the survival of spinal paralytics it is necessary to review the incidence of complications of the paralysis, as this affects life expectancy.

\section{TABLE III}

Incidence of kypho-scoliosis (number of laminectomies in brackets)

\begin{tabular}{|c|c|c|c|c|}
\hline $\begin{array}{l}\text { Number of } \\
\text { patients }\end{array}$ & $\begin{array}{l}\text { Vertebral } \\
\text { injury }\end{array}$ & $\begin{array}{c}\text { Conservative } \\
\text { management }\end{array}$ & $\begin{array}{l}\text { One or more } \\
\text { fusions }\end{array}$ & Total \\
\hline $\begin{array}{r}16 \\
7 \\
6\end{array}$ & $\begin{array}{l}\text { No bony injury } \\
\text { Minimal bony injury } \\
\text { Major bony injury }\end{array}$ & $\begin{array}{l}5(3) \\
I(I) \\
0\end{array}$ & $\begin{array}{l}5 \\
3(2) \\
2(2)\end{array}$ & $\begin{array}{r}\text { Io }(3) \\
4(3) \\
2(2)\end{array}$ \\
\hline 29 & & $6(4)$ & Io (4) & I6 (8) \\
\hline
\end{tabular}

Complications. The incidence of kypho-scoliosis was high, and is summarised in Table III. Sixteen of 29 patients demonstrated spinal curvatures at the time of review, Io of whom have had one or more fusions for the deformity. It is not the intention of this paper to discuss the indications for fusion, or its results, as the operations were performed by a number of different surgeons at different hospitals, the indications for surgery were usually not stated in the case notes and a number of pre- and post-operative X-rays were not available for study. However, the incidence of spinal curvature in relation to prior laminectomy has been recorded to see if there was any causal relationship between the two. The number of fusions has been listed to try and indicate the severity of deformity, assuming that fusions were performed on the more severe cases. Although the survival period of most of the children with kypho-scoliosis was 9 years or more, 
all of these had developed the deformity earlier than this. Two children had kypho-scoliosis only $2 \frac{1}{2}$ years after injury, one of whom had had a fusion one year after injury for a moderate deformity, whilst a 6-year-old child had a fusion only 4 months after injury because of an increasing kyphosis secondary to a laminectomy.

TABLE IV

Urological summary (26 patients)

\begin{tabular}{|c|c|c|c|c|}
\hline & $\begin{array}{l}\text { Survival } \\
\text { period }\end{array}$ & I.V.P. & Urine & Management \\
\hline Group I & $\begin{array}{l}0-5 \text { years } \\
\text { (I } 4 \text { patients) } \\
\text { (I died at } \\
3 \frac{1}{2} \text { months) }\end{array}$ & $\begin{array}{l}\text { I2 Normal } \\
\text { I Not done } \\
\text { I Slight left } \\
\text { caliectasis }\end{array}$ & $\begin{array}{l}7 \text { Infected } \\
5 \text { Sterile } \\
2 \text { Unknown }\end{array}$ & $\begin{array}{l}\text { I2 Catheter free } \\
2 \text { Indwelling catheter } \\
\text { (A left Leadbetters } \\
\text { was done on one) }\end{array}$ \\
\hline Group 2 & $\begin{array}{l}\text { 5-10 years } \\
\text { (6 patients) } \\
\text { (I died at } \\
7 \text { years) }\end{array}$ & $\begin{array}{l}4 \text { Normal } \\
\text { I Normal right } \\
\text { kidney, absent } \\
\text { left kidney } \\
\text { (I.V.P. two } \\
\text { years ago) } \\
\text { I Unknown }\end{array}$ & $\begin{array}{l}3 \text { Infected } \\
3 \text { Sterile }\end{array}$ & $\begin{array}{l}3 \text { Catheter free } \\
2 \text { Indwelling catheter } \\
\text { I Right hephrostomy } \\
\text { (in patient with } \\
\text { left nephrectomy) }\end{array}$ \\
\hline Group 3 & $\begin{array}{l}\text { IO-I } 5 \text { years } \\
\text { (3 patients) }\end{array}$ & $\begin{array}{l}2 \text { Chronic pyelo- } \\
\text { nephritis } \\
\text { I Bilateral } \\
\text { dilatation }\end{array}$ & 3 Infected & $\begin{array}{l}\text { I Catheter free } \\
\text { I Bilateral cutaneous } \\
\text { ureterostomy } \\
\text { I Suprapubic } \\
\text { cystostomy }\end{array}$ \\
\hline Group 4 & $\begin{array}{l}\text { More than } \\
\text { I5 years } \\
\text { (3 patients) }\end{array}$ & $\begin{array}{l}\text { I No function } \\
\text { right kidney } \\
\text { I Poor function } \\
\text { right kidney } \\
\text { I Normal }\end{array}$ & 3 Infected & $\begin{array}{l}\text { I Indwelling catheter } \\
\text { I U tube between } \\
\text { suprapubic cysto- } \\
\text { stomy and peno- } \\
\text { scrotal fistula } \\
\text { I Suprapubic cysto- } \\
\text { stomy }\end{array}$ \\
\hline
\end{tabular}

Five other patients had fusions soon after injury for a variety of reasons, three following laminectomy. None of these five had developed kypho-scoliosis, although not all demonstrated a spine in normal alignment. Thus, eight patients only (one dead after $3 \frac{1}{2}$ months) did not have kypho-scoliosis, or were not subjected to a fusion for other reasons. Five of these patients had no bony injury, none of whom had laminectomies. They have survived between $3 \frac{1}{2}$ months and 7 years at the time of this survey.

In only one of the I 5 patients who had a spinal fusion was there any record of soft tissue damage noted at operation-extensive anterior ligamentous and 
intervertebral disc damage was noted in an extension injury between the third and fourth lumbar vertebrae. There was no record of any soft tissue damage or bony injury at laminectomy or fusion in any of the patients who had no bony injury on $X$-ray. One patient remained on tracheostomy and assisted respiration until his death after $3 \frac{1}{2}$ months. He had recurrent chest infections. Three other patients still have tracheostomies and are on respirators; one, a child of 5 years, is still alive after I year with a complete tetraplegia below the second cervical segment, and another, an 8-year-old, had had a complete lesion below the sixth cervical segment for $3 \frac{1}{2}$ months. A girl with an incomplete tetraplegia below the eighth cervical segment from a birth injury has survived 18 years but has a permanent tracheostomy (and respirator by night). She has had multiple fusions for severe kypho-scoliosis. Another patient, aged 9 weeks at injury, has survived 9 years with a complete lesion below the seventh cervical segment, and is recorded as having 'recurrent chest infections'.

Urological follow-up is summarised in Table IV. Three of the four incomplete lesions in this series were very incomplete, are catheter free and have sterile urine, so they have been excluded from the Table. No patients have died of renal complications. None have a raised serum creatinine at present, so none are in renal failure, though all six of the Group 3 and 4 patients have serious urological problems which will reduce their life expectancy. The patients have been grouped into four periods of survival. In Group I, one patient died after a few months, another has bilateral vesico-ureteric reflux, but a normal pyelogram after $4 \frac{1}{2}$ years. Another patient has not been followed for 2 years, despite infected urine when last seen. One patient has had a Leadbetters operation for left-sided vesicoureteric reflux; the latest pyelogram shows left caliectasis.

In Group 2 one patient has had multiple renal and bladder stones, but has a normal pyelogram and normal blood chemistry 9 years after injury. Another child had an early left nephrectomy for hydro-nephrosis, was drained by a suprapubic catheter for some years, and now has a right nephrostomy 9 years after injury. He has not had an intravenous pyelogram for 2 years.

All three of the Group 3 patients have X-ray evidence of renal damage, all have infected urine, one has a suprapubic catheter, and another bilateral cutaneous ureterostomies (replacing a long-term suprapubic catheter).

In Group 4 two of the three patients who have survived more than 15 years have poor function of one kidney. One of them has a $U$ tube draining both suprapubically and through a peno-scrotal fistula. None of the six longest survivors has any elevation of B.U.N. or serum creatinine.

\section{DISCUSSION}

A high proportion of complete spinal cord lesions, 86 per cent., following closed trauma to the spine in children under 13 years of age is noted, with no evidence of vertebral fracture or dislocation in 55 per cent. of the cases ( 6 out of 29 patients). This substantiates the findings in the author's previous paper (Burke, I97I), and earlier papers by Melzak (1969) and Audic and Maury (I969). From the limited information available in the case notes reviewed the findings at laminectomy in children who have major traumatic spinal cord lesions, but no bony injury, are very similar to those seen in children with bony injury, minor or major, and are also similar to those found in adults. The finding of a 'con- 
stricted' segment of spinal cord of $4 \mathrm{~cm}$. in length above the cervical enlargement at autopsy in an II-month-old child is very strange. The length of the 'constriction' in such a small child suggest stretching of the spinal cord, not compression. The author has seen an autopsy specimen of the cervical spinal cord of an adult tetraplegic in which there was a similar gross attenuation. There was no evidence of compression. Glasauer and Cares (I972) recorded a similar finding in two children, one at laminectomy and the other at autopsy. They do not attempt to explain this phenomenon. The operative finding of a traumatised spinal cord six segments below the level of neurological section in one patient in this series, suggests a long segment of damaged spinal cord, unlike the usual short segment seen after trauma in adults. It is suggested that these findings add evidence to the hypothesis in the author's previous paper (Burke, I97I) that longitudinal stretching may be a significant factor in the pathogenesis of these lesions in children. From the available evidence there is nothing to disprove the supposition that an elastic vertebral column is distorted by trauma, but because of its elasticity in young children it does not disrupt, but the spinal cord is damaged as a result of the torsion, flexion and longitudinal traction forces exerted upon it. It is very significant that no mention was made by any of the surgeons of ligamentous or other soft tissue injury at operation.

It is not possible to make any statement on the early mortality of children after traumatic paraplegia, as all of these patients were treated elsewhere before transfer to Rancho Los Amigos Hospital. The acute death rate at other hospitals is not known. One early death, from respiratory causes, is noted, and another probable respiratory death occurred in a tetraplegic 7 years after injury. There have not yet been any deaths from renal causes, but the longest survival is only I 8 years, and five of the six longest survivors already have pyelographic evidence of renal damage, as does one who has survived 9 years and another less than 5 years. The long-term outlook for these children is bad, although none are yet showing any signs of renal decompensation.

Incidence of multiple pressure sores and joint contractures was high perhaps by Western European and Australian standards but not, in the author's experience, by American standards, where the primary cause is the shortage of civilian Spinal Injury Centres and long delayed admissions.

The incidence of kypho-scoliosis, much as it severe enough to require surgery, is high, and this has been noted by Kilfoyle et al. (1965) and many other writers. From a review of these patients there does not seem to be a consistent relationship between the evolution of kypho-scoliosis and prior laminectomy. The operation of laminectomy is obviously only one of many factors causing this complication, others being paralysis of paravertebral and trunk muscles, spasticity, unequal vertebral growth and posture. However, there is much evidence from this series that laminectomy is of no help in these patients. None improved neurologically after the operation, particularly when it was done to 'decompress' an extradural haematoma six segments below the level of clinical neurological section, and one, at least, deteriorated neurologically. Myelography also proved of no assistance in this series, either for diagnosis or planning of treatment. There is an even stronger case for a conservative management of the spine than in adults as the majority have a completely stable spine, and laminectomy is contra-indicated.

Traumatic paraplegia in children continues to fascinate the author. The pathogenesis and pathology remains unproven and, in a rare condition with a low 
early mortality it is difficult to envisage either quick or easy proof forthcoming. Possibly indirect proof from animal experiments may be obtained by comparing the results of trauma to the spine of mature and immature animals. The life expectancy of these patients appears to be based on the same factors as adults, and should be the same as adults if they can get through to adolescence safely. It is considered that the poor urological function in this series is related to delayed admission to a specialised centre, and urological management, which by the best neuro-urological standards today, has been poor, but the details are beyond the scope of this paper. It is anticipated that the urological results should be better with present knowledge and practice, and the author would hope that the urological evolution of these patients will not be quoted medico-legally as being the 'usual' fate of the paralytic child, but will be used only in its specific context of an isolated report on a single series of patients.

A high incidence of kypho-scoliosis complicates the management of the child, particularly as it is related to a higher incidence of pressure sores and contractures, and causes serious respiratory, and possibly urinary problems. A high standard of medical management and follow-up is required for these children until they reach late adolescence, after which they should be able to care for themselves rather than relying on another person, usually the mother.

\section{SUMMARY}

A series of 29 children treated at Rancho Los Amigos Hospital with traumatic paraplegia commencing under the age of I 3 years is reviewed. Eighty per cent. of these children are found to have major spinal cord lesions with minimal, or no vertebral injury. Observations at surgery and autopsy are used to try to explain the pathology of these lesions. The details of follow-up, including the incidence of various complications, are used to study the survival of these patients.

\section{RÉSUMÉ}

Une série de 29 enfants a été étudiée à l'hôpital du Ranch Los Amigos, avec des paraplégies post-traumatiques, ayant débuté au-dessous de l'âge de I 3 ans.

$80 \%$ de ces enfants étaient porteurs d'une lésion médullaire importante avec une atteinte vertébrale minime ou inexistante. Les observations effectuées au cours d'opérations ou d'autopsies sont utilisées pour essayer d'expliquer la pathologie de ces lésions. Les détails en ce qui concerne les suites, y compris les incidences des différentes complications, ont été utilisés pour étudier la survie de ces malades.

\section{ZUSAMMENFASSUNG}

Eine Serie von 29 unter $13 \mathrm{Jahr}$ alten Kindern mit traumatischer Paraplegie wird beschrieben.

$80 \%$ der Kinder hatten schwere Rückenmarksläsionen trotz minimaler oder fehlender vertebraler Schädigung.

Chirurgische und autoptische Beobachtungen versuchen die Pathologie dieser Läsionen zu erklären.

Einzelheiten der Nachsorge einschliesslich der folgenden Komplikationen werden für Überlebensdauer dieser Patienten angeführt.

Acknowledgement. The author wishes to thank the Staff of Rancho Los Amigos Hospital for permission to study hospital records and assistance with the project, in 
particular he is indebted to Dr. C. Bonnett, Chief, Spine and Hip Deformities Service, Dr. M. Hoffer, Chief, Cerebral Palsy and Children's Reconstructive Service and Dr. S. Stauffer, Chief, Spinal Cord Injuries Service, under whose care these patients are at present. The author would also like to express his gratitude to the Winston Churchill Memorial Trust and the University of Southern California who made this study possible.

\section{REFERENCES}

Audic, B. \& Maury, M. (I969). Int. F. Paraplegia, 7, Io.

Burke, D. C. (I97I). Int. F. Paraplegia, 9, I.

Glasauer, F. E. \& Cares, H. L. (I972). F.A.M.A. 219, 38.

Kilfoyle, R. M., Foley, J. J. \& Norton, P. L. (1965). 'f. Bone ft. Surg. 47A, 659.

MelzaK, J. (1969). Lancet, ii, 45. 